\title{
RAPPORTS FINALS DES COMMISSIONS TECHNIQUES DE LA RILEM
}

\author{
1975-1981
}

\author{
FINAL REPORTS \\ OF RILEM TECHNICAL COMMITTEES
}

\begin{abstract}
The effect of impact loading on building. State-of-the-Art Report (21-IL, No 44, 1975).
Durabilité du béton : Rapport Final/Durability of concrete/Final report (4-CDC, No 46, 1975).

Recommended principles for the control of quality and the judgement of acceptability of concrete $\left(10-\mathrm{SC}_{,} \mathrm{N}^{\circ} 47,1975\right)$.

Rapport fınal du groupe de travail « Adjuvants »/Fınal report of the working group on admixtures (11-A, No 48, 1975$)$.

Corrosion of reinforcement in concrete. State-of-the-Art Report (12-CRC, No 51, 1976).
\end{abstract}

Fibre concrete materials (19-FRC, № 56,1977$)$.

Report on behaviour of concrete in hot climate (2-HC, Part I, № 62, 1978, Part II, № 75, 1980).

Rapport final de la commission 20-TBS sur les essais in situ des structures/Final report of 20-TBS committee on testing building structures in situ (20-TBS, № 66, 1978).

The evaluation of external vertical surfaces of buildings. Final report of 27-EVS committee/Evaluation des surfaces externes des façades des constructions. Rapport final de la commission 27-EVS (No 76, 1980).

Properties of set concrete at early ages-State-of-the-art report (42-CEA, № 84, 1981).

A paraître/To be issued

Rapport final de la commission 23-GP/Final report of 23-GP committee ( $\left.N^{\circ} 85,1982\right)$. 